\title{
Bagaimanakah Kinerja Bank Umum Syariah di Indonesia?: Penilaian dengan Sharia Maqashid Index (SMI)
}

\author{
Rizki Amalia 1 \\ 1 Jurusan Perbankan Syariah, Fakultas Ekonomi dan Bisnis Islam, IAIN PALU. \\ Email: rizkissamalia91@yahoo.com
}

\section{ABSTRAK}

Penelitian ini bertujuan untuk mengukur kinerja Bank Umum Syariah di Indonesia tahun 2018 berdasarkan Sharia Maqasid Index (SMI). Dari tahun ke tahun, perkembangan Bank Umum Syariah di Indonesia makin pesat. Pesatnya perkembangan tersebut membuat Bank Umum Syariah harus selalu meningkatkan kinerjanya. Penilaiaan kinerja bank syariah dalam Annual Report selama ini hanya berdasarkan rasio-rasio keuangan saja, sehingga tidak bisa memberikan evaluasi terhadap halhal yang merupakan prinsip dasar dari bank syariah. Bank Syariah di harapkan bisa mencapai kesuksesan baik di dunia maupun di akhirat. Pendekatan Sharia Maqasid Index (SMI) digunakan untuk mengukur kinerja bank syariah berdasarkan prinsip-prinsip syariah dan keislaman. Objek dari penelitian ini adalah 14 Bank Umum Syariah yang terdaftar di OJK (Otoritas Jasa Keuangan). Data yang digunakan adalah data sekunder berupa data laporan keuangan yang telah diaudit dalam Annual Report Bank Umum Syariah. Penelitian ini menggunakan 3 variabel Maqashid Syariah yaitu yaitu Tahdzib al-Fard (Mendidik Individu), Iqamah al-Adl (Menegakan Keadilan), Jabl al-Maslahah (Menciptakan Kemaslahatan). Hasil yang didapatkan yaitu, Bank Panin Dubai Syariah memperoleh total nilai indikator kinerja tertinggi tahun 2018.
INFORMASI

ARTIKEL

Kata Kunci:

Bank Umum Syariah, Sharia Maqashid Index (SMI). 


\section{Jurnal Ilmu Perbankan dan Keuangan Syariah Vol.2 No. 1 Tahun 2020}

\section{PENDAHULUAN}

Ditengah hiruk-pikuk permasalahan pada bank-bank konvensional serta krisis moneter dan keuangan yang mengglobal saat ini, kehadiran Bank Syariah telah memberikan jalan keluar yang sangat tepat bagi umat Islam $^{1}$. Bank Syariah biasa disebut Islamic Banking, yaitu suatu sistem perbankan yang pelaksanaan operasionalnya tidak menggunakan sistem bunga (riba), spekulasi (maisir), dan ketidakpastian (gharar) ${ }^{2}$. Perkembangan Bank Syariah yang pesat merupakan sumbangsih terhadap sistem perekonomian di Indonesia.

Bank Syariah di Indonesia terdiri dari Bank Umum Syariah (BUS), Bank Pembiayaan Rakyat Syariah (BPRS), dan Unit Usaha Syariah (UUS). Bank Umum Syariah dan Unit Usaha Syariah memiliki kegiatan yang sama meliputi jasa dalam lalu lintas pembayaran, penghimpun dan penyalur dana yang menggunakan prinsip syariah. $^{3}$ Perbedaan utama yaitu, Unit Usaha Syariah masih merupakan bagian dari perusahaan induknya yaitu Bank Umum Konvensional. Unit Usaha Syariah merupakan unit kerja dari Bank Umum Konvensional yang melaksanakan kegiatan usahanya dengan prinsip syariah, sehingga laporan keuangannya bersifat konsolidasi dengan laporan keuangan perusahaan induknya. Berbeda dengan Unit Usaha

1 Muhammad Syafi'i Antonio. Bank Syariah dari teor

2 Zainuddin Ali. 2007. Hukum Perbankan Syariah, (Jakarta: Sinar Grafika, 2007)

${ }^{3}$ Nurdin, N., \& Mir'atun, M. a. (2018). Do

Government And Private Sharia Commercial Banks Practice Similar Financial Social Responsibility Disclosure. Hunafa: Jurnal Studia Islamika, 15(2), 285321.
Syariah, Bank Umum Syariah sudah berdiri sendiri, dengan melakukan pemisahan unit usaha dari perusahaan induknya, dan mempunyai akta pendirian sendiri sehingga bukan lagi merupakan anak perusahaan dari Bank Umum Konvensional. Laporan keuangan Bank Umum Syariah pun berasal dari semua kegiatan keuangan mereka sendiri dalam suatu periode.

Bank Umum Syariah kini makin banyak dilirik oleh masyarakat. Bank Umum Syariah harus berlomba-lomba menciptakan produk unggulan agar bisa meningkatkan penjualan, menimbulkan rasa bangga bagi nasabah, menimbulkan kepercayaan dan kepuasan pada nasabah. Selain itu, adanya pelayanan prima, SDM yang profesional, Sarana dan Prasarana yang cepat dan tepat, adalah hal-hal yang dilakukan untuk menjaga nama baik mereka ${ }^{4}$.

Perkembangan Bank Umum Syariah di Indonesia membuat daya saing antar Bank Umum Syariah menjadi semakin tinggi. Bank umum syariah harus dapat memberikan kinerja yang terbaik tiap tahunnya, untuk selalu mendapatkan kepercayaan dari masyarakat, stakeholder, dan para investor baik dari segi keuangan maupun non keuangan. Peningkatan kinerja keuangan pada Bank Umum Syariah diharapkan berbanding lurus dengan kinerja berdasarkan konsep Islam. Melalui kinerja berbasis syariah yang memadai, Bank Umum Syariah dapat membuktikan kepada para pemangku kepentingan bahwa sistem bisnis yang diterapkan relevan dengan konsep, nilai, dan etika Islam ${ }^{5}$.

${ }^{4}$ M. Nur Rianto Al Arif. Dasar-dasar Pemasaran Bank Syariah. (Bandung: Alfabeta, 2010).

${ }^{5}$ Mega Silvia., Isni Andriana, Marwa, dan 


\section{Jurnal Ilmu Perbankan dan Keuangan Syariah Vol.2 No. 1 Tahun 2020}

Pengukuran kinerja keuangan perbankan sangat penting dilakukan karena pengukuran kinerja merupakan gambaran pencapaian prestasi yang telah dilakukan dalam kegiatan operasionalnya sehingga dengan adanya pengukuran tersebut dapat diketahui kondisi kesehatan suatu bank ${ }^{6}$. Dalam usia lebih dari seperempat abad, Perbankan Syariah di Indonesia masih belum memiliki instrumen sendiri untuk mengukur kinerja dan masih menerapkan instrumen pengukuran ortodoks yang hanya terbatas pada pengukuran rasio keuangan ${ }^{7}$. Hal tersebut memiliki kesamaan dengan Bank Konvensional dalam hal pengukuran kinerja.

Pengukuran kinerja Bank Umum Syariah yang ada dalam laporan tahunan selama ini hanya menggunakan rasio-rasio keuangan sama seperti bank konvensional pada umumnya.

Pengukuran rasio keuangan yang digunakan oleh bank konvensional seperti metode CAMEL (Capital, Asets, Management, Earning, Liquidity), Return on Asset (ROA), Return on Equity (ROE), Data Envelopment Analysis $(D E A)^{8}$. Penilaian

Taufiq Marwa. "Performance of Indonesia Islamic Bank Based on Maqashid Sharia Index: Stakeholder Theory Perspective" Doarj, International Journal of Business, Accounting, and Management, Vol. 4 Issue 1, 2019, PP 1-9.

\footnotetext{
6 Aneu Cakhyaneu, "Pengukuran Kinerja Bank Umum Syariah di Indonesia Berdasarkan Sharia Maqashid Index (SMI)". Awaluna: Jurnal Ekonomi dan Keuangan Syariah, Vol.2, No.2, 2018, hlm 154165.

7 Mokhammad Ikhsan Ramdhoni dan Firdaus Ahmad Fauzi. "Islamic Bank Performance: an Assesment using Sharia Maqashid Index, Sharia Comformity and Profitability, and CAMELS". Polban, International Journal of Applied Business Research. Vol. 2 No. 1, 2020, PP. 15-30.

${ }^{8}$ M. Al Ghifari. "Analisis Kinerja Perbankan Syariah di Indonesia dan Malaysia dengan Pendekatan Maqashid Sharia Index". Jurnal
}

kinerja perbankan syariah yang didasarkan pada perhitungan rasio keuangan CAMEL dan lainnya memiliki beberapa kelemahan. Pertama, dengan menjadikan rasio keuangan sebagai penentu utama dari penilaian kinerja perbankan akan membuat manajer bertindak mengabaikan rencana jangka panjang. Kedua, mengabaikan aspek pengukuran non keuangan dan aset tetap akan memberikan pandangan yang keliru pada manajer bank baik pada masa kini maupun di masa depan. Ketiga, kinerja perbankan yang hanya didasarkan kinerja keuangan di masa lalu tidak mampu membawa perusahaan untuk mencapai tujuannya dimasa yang akan datang9. Bank Umum Syariah dalam menjalankan tugas dan fungsinya, tidak hanya diharuskan mencari keuntungan semata, namun harus selalu menjalankan prinsip syariah untuk mencari keberkahan dunia dan akherat. Adanya asumsi dan kondisi tersebut, membuat para peneliti mengembangkan suatu konsep penilaian kinerja yang tidak hanya mengukur kinerja dalam bentuk rasio-rasio keuangan saja, namum perlu diadakan pengembangan khususnya pada aspek syariah dan sesuai dengan prinsip islam.

Bedoui dan Mansour ${ }^{10}$ menyatakan bahwa pandangan Islam tentang kinerja sangat berkaitan dengan etika dan tidak terbatas pada dimensi keuangan, tetapi

Ekonomi dan Perbankan Syariah Vol 3 No 2, 2015

9 Muhammad Syafii Antonio, et al. "An Analysis of Islamic Banking Performance: Maqashid Index Implementation in Indonesia and Jordania". (IIUM Institute of Islamic Banking and Finance. Journal of Islamic Finance, 1(1), 2012) hlm. 1229

10 Houssemeddine Bedoui dan Mansour Walid. "Islamic Banks Performance and Maqashid alShariah", Makalah Disampaikan pada AsiaPasific Economic Association Conference, di Osaka, Jepang, 2013, 27 s.d 28 Juli 


\section{Jurnal Ilmu Perbankan dan Keuangan Syariah Vol.2 No. 1 Tahun 2020}

meliputi dimensi tambahan yang membuat perusahaan tidak berorientasi pada pemilik tetapi untuk semua pemangku kepentingan dan masyarakat secara keseluruhan, ini yang menjadi hal penting pada kinerja berdasarkan konsep Maqashid Syariah. Pengukuran ketercapaian tujuan syariah pada perbankan tersebut dikenal dengan Sharia Maqashid Index (SMI) yang dikembangkan dari teori Maqashid Syariah oleh Abu Zahrah yang mencakup tiga tujuan syariah yaitu Tahdzib al-Fard (Mendidik Individu), Iqamah al-Adl (Menegakan Keadilan) dan Jabl al-Maslahah (Mencapai Kesejahteraan) ${ }^{11}$.

Mohammed dan Taib ${ }^{12}$ menjelaskan bahwa pengukuran kinerja perbankan syariah dengan menggunakan variabel Maqashid Syariah menunjukkan persentase yang lebih baik dibandingkan pengukuran kinerja perbankan konvensional. Perbincangan tentang Index Maqashid sebagai alat untuk mengukur kinerja Perbankan Syariah semakin luas dan intensif dikalangan para cendekiawan muslim ${ }^{13}$. Penelitian terdahulu yang meneliti tentang penilaian kinerja Bank Umum Syariah menggunakan Sharia Maqashid Index (SMI) dilakukan melalui tahun ke tahun. Penelitian yang dilakukan oleh Muhammad Syafii Antonio yang meneliti tentang kinerja perbankan syariah di Indonesia dan Yordania, mengambil

11 Cakhyaneu, Aneu., Op. Cit., hlm 156

12 Mohammed dan Taib "Testing The Performance Measured Based on Maqashid AlShariah (PMMS) Model on 24 Selected Islamic and Conventional Banks". Malaysia: IIUM. 2009

13 Abdul Aziz Yahya Saoqi."Analizing the Performance Of Islamic Banking in Indonesia and Malaysia: Maqashid Index Approach". Jurnal Ekonomi Islam Uhamka, Vol. 8, No.1, 2017, hlm 29-50 data pada tahun 2008-2010. Hasil yang didapatkan yaitu Bank Muamalat Indonesia berada posisi pertama dengan total nilai Sharia Maqashid Index (SMI) paling tinggi di antara semua objek penelitian. Penelitian seanjutnya dilakukan oleh Aneu Cakhyaneu yang melakukan penelitian kinerja Bank Umum Syariah menggunakan Sharia Maqhasid Index dari tahun 2011-2016. Hasil yang didapatkan yaitu Bank Syariah Mandiri berada posisi pertama dengan Sharia Maqashid Index sebesar 27,69\%. Penelitian selanjutnya dilakukan oleh Restiana Wahyuni yang melakukan penelitian kinerja Bank Umum Syariah menggunakan Sharia Maqhasid Index dari tahun 2017, dengan hasil Bank Panin Syariah yang mendapatkan peringkat pertama dengan Shariah Maqashid Index (SMI) sebesar 36,41\%.

Penelitian ini bermaksud untuk menilai kinerja perbankan syariah ditinjau dari Maqashid Syariah dengan menggunakan pendekatan Sharia Maqashid Index (SMI) dan metode The Simple Additive Weighting (SAW) serta untuk mendeskripsikan kinerja Bank Umum Syariah di Indonesia pada tahun 2018. Penggunaan metode ini diharapkan dapat melengkapi penelitian sebelumnya dalam pengukuran kinerja perbankan syariah, sehingga hal tersebut membuat penulis tertarik mengangkat penelitian dengan judul ini.

\section{TINJAUAN PUSTAKA \\ 2.1 Prinsip Perbankan Syariah}

Bank syariah adalah suatu lembaga keuangan yang berfungsi sebagai perantara bagi pihak yang berkelebihan dana dan pihak yang berkekurangan dana untuk kegiatan usaha dan kegiatan lainnya sesuai 
dengan hukum Islam ${ }^{14}$. Bank Syariah biasa disebut Islamic Banking, yaitu suatu sistem perbankan yang pelaksanaan operasionalnya tidak menggunakan sistem bunga (riba), spekulasi (maisir), dan ketidakpastian (gharar). ${ }^{15}, 16$ Menurut jenisnya Bank Syariah terdiri atas Bank Umum Syariah (BUS), Bank Pembiayaan Rakyat Syariah (BPRS) dan Unit Usaha Syariah (UUS) ${ }^{17}$.

Hal yang paling mendasar sebagai pembeda antara bank syariah dan bank konvensional terletak di akadnya. Bank konvensional melakukan akad berbasis riba, sedangkan pada Bank Syariah akad yang digunakan adalah akad berbasis transaksi riil yang diinginkan ${ }^{18}$.

Produk bank syariah memiliki spesifikasi tersendiri sebagai pembeda dengan bank konvensional seperti akad jual beli yang terdiri dari Murabahah, Salam, dan Istishna, akad bagi hasil yang terdiri dari Mudharabah dan Musyarakah, serta sewa-menyewa yang terdiri dari Ijarah dan

${ }^{14}$ Riky Ramadhani dan Evi Mutia, 2016, “Analisis Perbandingan Kinerja Perbankan Syariah di Indonesia dan Malaysia Ditinjau dari Maqashid Sharia Index", Paper disampaikan pada Simposium Nasional Akuntansi XIX, Lampung, 2016.

${ }^{15}$ Nurdin, N. (2016). The Roles of Information Technology in Islamic Bank Knowledge Management: A study of Two Syariah Banks in Palu. Hunafa: Jurnal Studia Islamika, 13(2), 181-217. https://doi.org/https://doi.org/10.24239/jsi.v13i2. 444.181-217

${ }^{16}$ Nurdin, N. (2019). Knowledge Integration Strategy in Islamic Banks. In A. Helena \& S.

Bernardete (Eds.), The Role of Knowledge Transfer in Open Innovation (pp. 118-138). IGI Global. https://doi.org/10.4018/978-1-5225-5849-1.ch006

17 Wiroso, Produk Perbankan Syariah. (Jakarta: LPFE Usakti, 2011).

18 Ahmad Ifham. Ini Lho Bank Syariah! Memahami Bank Syariah dengan Mudah. (Jakarta: Gramedia Pustaka Utama, 2015).
Ijarah muntahiya bit tamlik. ${ }^{19}$

Disamping itu, Perbankan Syariah menggunakan akad tabarru' untuk produk Qard, Qardhul hasan, Wakalah, Kafalah, dan Rahn ${ }^{20}$. Prinsip keuangan Islam pada perbankan syariah sebagaimana yang diatur dalam Al-Quran dan As-sunnah adalah pelarangan riba, pembagian risiko, menganggap uang sebagai modal potensial, larangan melakukan kegiatan spekulatif, kesucian kontrak dan aktivitas harus sesuai syariah ${ }^{21}$. Perbankan Syariah dalam menjalankan operasionalnya secara legal formal harus berpedoman pada regulasi yang ada di Indonesia yaitu Fatwa Dewan Syariah Nasional Majelis Ulama Indonesia (DSN MUI), Undang-undang Perbankan Syariah, Peraturan Bank Indonesia (PBI) dan Peraturan OJK (POJK) untuk Perbankan Syariah, Pedoman Akuntansi Perbankan Syariah (PAPSI), Pernyataan Standar Akuntansi Keuangan (PSAK Syariah) $^{22}$.

Bank Umum Syariah dituntut harus selalu memberikan kualitas yang terbaik terhadap kinerjanya. Penilaian kinerja sangat penting dilakukan untuk mengetahui gambaran kondisi pengelolaan organisasi secara menyeluruh pada Bank Syariah. Penilaian kinerja dapat dilihat dari sisi kinerja keuangan. Kinerja keuangan merupakan gambaran kondisi keuangan

${ }^{19}$ Nurdin, N., \& Yusuf, K. (2020).

Knowledge management lifecycle in Islamic bank: the case of syariah banks in Indonesia. International Journal of Knowledge Management Studies, 11(1), 59-80. https://doi.org/10.1504/ijkms.2020.105073

20 Adiwarman Karim. Bank Islam: Analisis Fiqih dan Keuangan. (Edisi Ketiga. Jakarta: PT Raja Grafindo Persada, 2006)

21 Sri Nurhayati dan Wasilah, Akuntansi Syariah di Indonesia. Edisi Empat. (Jakarta: Salemba Empat, 2015)

${ }^{22}$ Ahmad Ifham., Op Cit., hlm. 3 
dalam suatu periode tertentu, yang dapat dilihat dalam laporan keuangan.

\subsection{Konsep Maqashid Sharia dan Sharia Maqashid Index (SMI)}

Dalam kamus bahasa Arab, Maqshad dan Maqashid berasal dari akar kata Qashd. Maqashid adalah kata yang menunjukkan banyak (jamak), mufradnya adalah Maqashid yang bermakna maksud, sasaran, prinsip, niat, tujuan, tujuan akhir23. Maqashid Syariah menurut Al Syatibi dalam Al Ghifari, secara bahasa terdiri dari dua kata yaitu Maqashid dan Al-syariah. Maqashid berarti kesengajaan atau tujuan sedangkan Al-syariah berarti jalan menuju sumber air, dapat pula dikatakan sebagai jalan ke arah sumber pokok kehidupan. Berdasarkan pengertian tersebut, dapat disimpulkan bahwa Maqashid Syariah memiliki tujuan untuk menciptakan kesejahteraan umat.

Untuk menciptakan kesejahteraan umat, maka para ahli ushul fiqh meneliti dan menetapkan lima unsur pkok tujuan syariah yang harus dijaga yaitu memelihara agama (Hifdz Ad-Din), memelihara jiwa (Hifdz An-Nafs), memelihara akal (Hifdz $A l^{\prime} A q l$ ), memelihara keturunan (Hifdz An$\mathrm{Nasb}$ ) dan memelihara harta (Hifdz AlMaal) ${ }^{24}$. Menurut Abu Zahrah 3 tujuan syariah, yaitu Tahdzib al Fard (Mendidik Individu), Iqamah al-adl (Menegakan Keadilan) dan Jabl al-Maslahah (Mencapai Kesejahteraan). Maka, 3 tujuan inilah yang menjadi acuan sebagai variabel dalam Syariah Maqashid Index (SMI) yang dikembangkan oleh, Mustafa Omar Mohammed, Dzuljastri Abdul Razak dan Fauziah Md Taib, Dalam penelitian mereka

23 Jasser Auda. Membumikan Hukum Islam Melalui Maqashid Syariah. (Bandung: Mizan Pustaka, 2015)

24 Aneu Cakhyaneu, Op.Cit., Hlm 157 yang berjudul "The Performance Measures of Islamic Banking Based On The Maqashid Frameork", pada tahun 2008. Sharia Maqashid Index (SMI) adalah pengukuran kinerja perbankan syariah yang sesuai dengan tujuan dan karakteristik perbankan syariah.

Mengadopsi metode sekaran, mereka menurunkan tiga tujuan Maqashid Syariah tersebut menjadi 9 dimensi dan 10 elemen. Sepuluh elemen itu berubah menjadi rasio kinerja. Mendidik individu pada Maqashid pertama berarti pengembangan pengetahuan dan keahlian individu sehingga nilai spiritual meningkat. Maqashid kedua adalah keadilan, bank syariah harus memastikan kejujuran dan keadilan dalam semua transaksi dan kegiatan usaha yang tercangkup dalam produk, harga dan ketentuan kontrak. Selain itu seluruh kontrak (akad) harus terbebas dari unsur ketidakadilan seperti maysir, gharar, dan riba. Adapun Maqashid ketiga yang disebut maslahah, dalam hal ini harus mengembangkan proyek investasi dan pelayanan sosial untuk meningkatkan kesejahteraan masyarakat.

Sharia Maqashid Index (SMI) dipahami sebagai tujuan akhir dari syariah yang mengarah kepada nilai-nilai kesejahteraan dan manfaaat serta menghilangkan penderita.

\section{METODOLOGI PENELITIAN}

\subsection{Jenis Penelitian}

Jenis penelitian ini merupakan penelitian kuantitatif dengan pendekatan deskriptif. Penelitian deskriptif kuantitatif hanya memberikan gambaran tentang variabel dari sebuah fenomena atau kejadian yang diteliti25. Studi deskriptif pada dasarnya tidak memerlukan pengujian lebih lanjut misalnya

\footnotetext{
25 Riki Ramadhani dan Evi Mutia, Op.Cit.,
} Hlm 6 
mempelajari hubungan antara variabel satu dan variabel lainnya, atau pengujian hipotesis mengunakan alat statistik. Penelitian ini menghitung rasio-rasio pada 3 tujuan Maqashid Shariah yaitu Tahdzib alFard (Mendidik Individu), Iqamah al-Adl (Menegakan Keadilan), Jabl al-Maslahah (Menciptakan Kemaslahatan) pada Bank Umum Syariah yang terdaftar pada OJK tahun 2018

\subsection{Sumber dan Teknik Pengambilan Data}

Sumber data pada penelitian ini yaitu data sekunder yang berupa data-data keuangan dari laporan tahunan (Annual Report) dengan tahun pelaporan tahun 2018, pada 14 Bank Umum Syariah yang terdaftar di OJK. Annual Report tersebut diperoleh dari masing-masing laman resmi Bank Umum Syariah tersebut.

Teknik pengumpulan data dilakukan dengan cara dokumentasi dan studi kepustakaan. Studi Kepustakaan bertujuan untuk memperoleh konsep dan landasan teori dengan mengkaji berbagai literatur, jurnal dan dokumen-dokumen yang berkaitan dengan objek penelitian ${ }^{26}$.

3.3 Populasi, Sampel, dan Teknik Pengambilan Sampel.

Populasi dalam penelitian ini adalah Bank Umum Syariah yang beroperasi di Indonesia dan terdaftar pada OJK tahun 2018, yaitu sebanyak 14 Bank Umum Syariah. Semua populasi dalam penelitian ini dijadikan sampel, sehingga teknik pengambilan sampelnya menggunakan sampling jenuh. sampling jenuh adalah Teknik penentuan sampel bila semua anggota populasi digunakan sebagai sampel. Istilah lain jenuh adalah sensus ${ }^{27}$. Populasi menungkinkan untuk dijadikan

${ }^{26}$ Aneu Cakhyaeu, Op. Cit., Hlm 159

27 Sugiyono, Metode Penelitian Bisnis (Bandung: Alfabeta, 2007) sampel mana kala jumlah anggota populasi hanya sedikit.

Adapun Bank Umum Syariah yang menjadi objek dalam penelitian ini beserta singkatannya pada tabel indikator kinerja Bank Umum Syariah dapat dilihat pada tabel berikut ini. 
Tabel 1. Bank Umum Syariah di Indonesia yang terdaftar pada OJK tahun 2018

\begin{tabular}{|c|c|c|}
\hline No. & Bank Umum Syariah & $\begin{array}{l}\text { Singkatan pada Tabel } \\
\text { Indikator Kinerja SMI }\end{array}$ \\
\hline 1 & PT. Bank Muamalat Inonesia & BMI \\
\hline 2 & PT. Bank Syariah Mandiri & BSM \\
\hline 3 & PT. Bank BNI Syariah & BNIS \\
\hline 4 & PT. Bank BRISyariah & BRIS \\
\hline 5 & PT. BCA Syariah & BCAS \\
\hline 6 & PT. Bank Panin Dubai Syariah & BPDS \\
\hline 7 & PT. Bank Mega Syariah & BMS \\
\hline 8 & PT. Bank Syariah Bukopin & BSB \\
\hline 9 & PT. Bank Tabungan Pensiunan Nasional Syariah & BTPNS \\
\hline 10 & PT. Maybank Syariah Indonesia & MAYBS \\
\hline 11 & PT. Bank Victoria Syariah & BVS \\
\hline 12 & PT. Bank Jabar Banten Syariah & BJBS \\
\hline 13 & PT. Bank Aceh Syariah & BAC \\
\hline 14 & PT. BPD Nusa Tenggara Barat Syariah & BNTBS \\
\hline
\end{tabular}

Sumber: OJK, Statistik Perbankan Syariah di Indonesia tahun 2018

\subsection{Operasionalisasi Variabel}

Pada penelitian ini, variabel yang digunakan berdasarkan metode Sharia Maqashid Index (SMI) sebagai metode yang digunakan untuk mengukur kinerja Bank Umum Syariah. Melalui metode sekaran (2000), karakteristik perilaku-perilaku yang akan diukur diturunkan ke dalam suatu konsep, yang dinotasikan sebagai (C). Konsep akan diturunkan lagi ke dalam beberapa dimensi yang akan lebih mudah diamati dan terukur yang dinotasikan dengan $(\mathrm{D})$

Dimensi akan diturunkan lagi ke dalam beberapa elemen yang lebih jelas pengukurannya yang dinotasikan dengan (E) (Syofyan, Andriani., 2017). Mohammed, Razak dan Taib (2008) mengadopsi metode sekaran tersebut untuk menyusun definisi operasional variabel Maqashid Syariah menjadi suatu alat ukur untuk mengukur kinerja perbankan syariah. Adapun Operasionalisasi variabelnya sebagai berikut. 
Vol.2 No. 1 Tahun 2020

\begin{tabular}{|c|c|c|c|}
\hline Tujuan Syariah & Dimensi & Elemen & Indikator/Rasio Kinerja \\
\hline \multirow{4}{*}{$\begin{array}{l}\text { Pendidikan } \\
\text { (Tahdib Al-Fard) }\end{array}$} & \multirow{2}{*}{$\begin{array}{l}\text { D1. Kemajuan } \\
\text { Pengetahuan }\end{array}$} & $\begin{array}{l}\text { E1. Hibah } \\
\text { Pendidikan/Donasi }\end{array}$ & $\begin{array}{l}\text { R1. Hibah Pendidikan/ Total } \\
\text { Biaya }\end{array}$ \\
\hline & & E2. Penelitian & $\begin{array}{l}\text { R2. Biaya Penelitian/ Total } \\
\text { Biaya }\end{array}$ \\
\hline & $\begin{array}{l}\text { D2. Menanamkan } \\
\text { Keterampilan baru dan } \\
\text { perubahan }\end{array}$ & E3. Pelatihan & $\begin{array}{l}\text { R3. Biaya Pelatihan/Total } \\
\text { Biaya }\end{array}$ \\
\hline & $\begin{array}{l}\text { D3. Menciptakan } \\
\text { kesadaran akan } \\
\text { Perbankan Syariah }\end{array}$ & E4. Publikasi & $\begin{array}{l}\text { R4. Biaya Publikasi/Total } \\
\text { Biaya }\end{array}$ \\
\hline \multirow{3}{*}{ 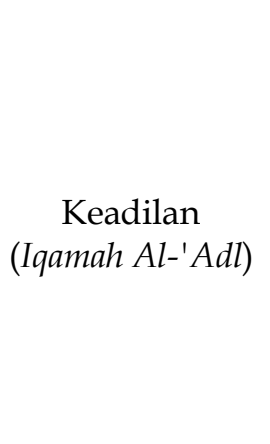 } & $\begin{array}{l}\text { D4. Hasil yang adil dan } \\
\text { setara }\end{array}$ & $\begin{array}{l}\text { E5. Pengembalian } \\
\text { yang adil }\end{array}$ & $\begin{array}{l}\text { R5. Laba Usaha/ Total } \\
\text { Pendapatan }\end{array}$ \\
\hline & $\begin{array}{l}\text { D5. Produk dan Layanan } \\
\text { Murah }\end{array}$ & $\begin{array}{l}\text { E6. Distribusi } \\
\text { Fungsional }\end{array}$ & $\begin{array}{l}\text { R6. Pembiayaan Mudharabah } \\
\text { dan Musyarakah/Total } \\
\text { Pembiayaan }\end{array}$ \\
\hline & $\begin{array}{l}\text { D6. Eliminasi } \\
\text { Ketidakadilan }\end{array}$ & $\begin{array}{l}\text { E7. Pendapatan } \\
\text { Bebas Bunga }\end{array}$ & $\begin{array}{l}\text { R7. Pendapatan Bebas } \\
\text { Bunga/Total Pendapatan }\end{array}$ \\
\hline \multirow{3}{*}{$\begin{array}{l}\text { Kesejahteraan } \\
\text { (Jabl al Maslahah) }\end{array}$} & D7. Profitabilitas Bank & $\begin{array}{l}\text { E8. Rasio } \\
\text { Profitabilitas Bank }\end{array}$ & R8. Laba Bersih/Total Aset \\
\hline & $\begin{array}{l}\text { D8. Redistribusi } \\
\text { Kekayaan dan } \\
\text { Pendapatan }\end{array}$ & $\begin{array}{l}\text { E9. Pemerataan } \\
\text { Pendapatan }\end{array}$ & R9. Zakat/Laba Bersih \\
\hline & $\begin{array}{l}\text { D9. Investasi pada Sektor } \\
\text { Riil }\end{array}$ & $\begin{array}{l}\text { E10. Investasi pada } \\
\text { Sektor Riil }\end{array}$ & $\begin{array}{l}\text { R10. Investasi pada Sektor } \\
\text { Riil/ Total Investasi }\end{array}$ \\
\hline
\end{tabular}

Sumber: Mohammed, Razak, Dzuljastri dan Taib (2008)

\subsection{Metode Analisa Data}

Data yang telah diambil dianalisis menggunakan metode Sharia Maqhasid Index (SMI) untuk mendapatkan hasil dari kinerja Bank Umum Syariah Tahun 2018.

Shariah Maqashid Index (SMI), sebagai metode pengukuran kinerja telah dikembangkan oleh beberapa ahli dan pakar dalam bidang figh, perbankan syariah dan ekonomi syariah.

Kemudian mereka melakukan verifikasi terhadap model, sekaligus menetapkan bobot untuk setiap komponen rasio tersebut, untuk menentukan apakah rasio atau ukuran kinerja dapat diterima dan terukur secara matematis. Bobot rata-rata yang diberikan oleh para ahli syariah disajikan pada tabel dibawah ini.

Tabel 3. Bobot Varabel dan Bobot Atribut Sharia Maqashid Index (SMI)

\begin{tabular}{|c|c|c|c|}
\hline Variabel & $\begin{array}{c}\text { Bobot Rata-rata } \\
\text { Variabel } \\
(\text { dari 100\%) }\end{array}$ & Atribut & $\begin{array}{c}\text { Bobot Rata-rata } \\
\text { Atribut } \\
(\text { dari 100\%) }\end{array}$ \\
\hline
\end{tabular}




\begin{tabular}{|c|c|c|c|}
\hline \multirow{5}{*}{$\begin{array}{c}\text { Pendidikan } \\
\text { (Tahdib al-Fard) }\end{array}$} & \multirow{5}{*}{30} & E1. Hibah Pendidikan/Donasi & 24 \\
\hline & & E2. Penelitian & 26 \\
\hline & & E3. Pelatihan & 27 \\
\hline & & E4. Publikasi & 23 \\
\hline & & Total & 100 \\
\hline \multirow{4}{*}{$\begin{array}{c}\text { Keadilan } \\
\text { (Iqamah al-'Adl) }\end{array}$} & \multirow{4}{*}{41} & E1. Pengembalian yang adil & 30 \\
\hline & & E2. Distribusi Fungsional & 32 \\
\hline & & E3. Pendapatan Bebas Bunga & 38 \\
\hline & & Total & 100 \\
\hline \multirow{3}{*}{$\begin{array}{c}\text { Kesejahteraan } \\
\text { (Jabl al- } \\
\text { Maslahah) }\end{array}$} & \multirow{3}{*}{29} & E1. Rasio Profitabilitas Bank & 33 \\
\hline & & E2. Pemerataan Pendapatan & 30 \\
\hline & & E3. Investasi pada sektor riil & 37 \\
\hline Total & 100 & Total & 100 \\
\hline
\end{tabular}

Sumber : Mohammed, Razak, dan Taib (2008)

Dalam melakukan analisis menggunkan pendekatan Sharia Maqashid Index (SMI) ada tiga langkah yang akan dilakukan untuk mengukur kinerja Sharia Maqashid Index (SMI) yaitu:

* Menilai setiap rasio kinerja maqashid syariah yang terdiri dari sepuluh elemen rasio dengan indikator kinerja.

Adapun indikator kinerjanya yaitu:

a) Hibah Pendidikan dibagi dengan total biaya $\left(R^{1}\right)$.

b) Biaya penelitian dibagi dengan total biaya $\left(R^{2}\right)$.

c) Biaya pelatihan dibagi dengan total biaya $\left(R^{3}\right)$.

d) Biaya publisitas dibagi dengan total biaya $\left(\mathrm{R}^{4}\right)$.

e) Laba Usaha dibagi dengan total pendapatan $\left(R^{5}\right)$.

f) Jumlah pembiayaan mudharabah dan musyarakah dibagi dengan total investasi $\left(\mathrm{R}^{6}\right)$.

g) Pendapatan non bunga dibagi dengan total pendapatan $\left(R^{7}\right)$.

h) Pendapatan dibagi dengan total aset $\left(R^{8}\right)$.

i) Zakat dibagi dengan pendapatan bersih $\left(\mathrm{R}^{9}\right)$.

j) Investasi pada sektor riil dibagi dengan total investasi $\left(\mathrm{R}^{10}\right)$.
Menentukan peringkat dari Bank Umum Syariah berdasarkan Indikator Kinerja (IK)

Penentuan peringkat ini dilakukan dengan menggunakan Simple Additive Weighting Method (SAW) dengan cara pembobotan, agregat dan proses menentukan peringkat (weighting, aggregating and ranking processes) $)^{28}$. Menghitung Indikator Kinerja menggunakan metode Simple Additive Weighting (SAW), yaitu dengan cara perkalian antara rasio dengan bobot Sehingga jika dinotasikan dalam bentuk rumus:

$$
I K=W x E x R
$$

Keterangan :

IK : Indikator Kinerja

$W$ : Bobot Variabel Maqashid Syariah

E : Bobot untuk Elemen pada Variabel Maqashid Syariah

$R$ : Ukuran Kinerja Sampel berdasarkan Rasio Elemen.

28 Mohammed Mustafa Omar, et al. "The Performance Measures of Islamic Banking Based on the Maqashid Framework". Paper Presented at the IIUM International Accounting Conference (INTAC IV). 2008, Putra Jaya Marroitt, Malaysia, 25 Juni. 
Rumus di atas kemudian akan di gunakan pada tiap tujuan/variabel dari Maqashid Syariah. Secara matematis proses menentukan indikator kinerja dengan tingkat Sharia Maqashid Index (SMI) tersebut dapat dijelaskan sebagai berikut:

\section{a. Tahzib al-Fard (Mendidik Individu).}

Indikator kinerja untuk tujuan yang pertama IK (01) yaitu:

$$
\begin{aligned}
I K 01= & W^{1} x E^{1} x R^{1}+W^{1} x E^{2} x R^{2} \\
& +W^{1} x E^{3} x R^{3}+W^{1} x E^{4} x \\
& R^{4}
\end{aligned}
$$

Atau disederhanakan menjadi :

$$
\begin{gathered}
I K 01=W^{1}\left(E^{1} x R^{1}+E^{2} x R^{2}+E^{3} x\right. \\
\left.R^{3}+E^{4} x R^{4}\right)
\end{gathered}
$$

Keterangan:

$$
\begin{aligned}
& \text { IK } 01 \text { : Indikator kinerja pada } \\
& \text { tujuan pertama dari } \\
& \text { Maqashid Syariah } \\
& \text { Tahdzib al-Fard } \\
& \text { (Mendidik Individu) } \\
& W^{1} \quad \text { : Bobot Variabel untk } \\
& \text { Tahdzib al-Fard } \\
& \text { (Mendidik Individu) } \\
& E^{1} \quad \text { : Bobot untuk elemen } \\
& \text { pertama pada } 01 \\
& \text { (Hibah Pendidikan) } \\
& E^{2} \quad \text { : Bobot untuk elemen } \\
& \text { kedua pada } 01 \\
& \text { (Penelitian) } \\
& E^{3} \quad \text { : Bobot untuk elemen } \\
& \text { ketiga pada } 01 \\
& \text { (Pelatihan) } \\
& E^{4} \quad \text { : Bobot untuk elemen } \\
& \text { keempat pada } \\
& \text { 01(Publisitas) } \\
& R^{1} \quad \text { : Rasio kinerja untuk } \\
& \text { elemen pertama pada } \\
& 01 \\
& R^{2} \quad \text { : Rasio kinerja untuk } \\
& \text { elemen kedua pada } 01 \\
& R^{3} \quad \text { : Rasio kinerja untuk } \\
& \text { elemen ketiga pada } 01 \\
& R^{4} \quad \text { : Rasio kinerja untuk }
\end{aligned}
$$

elemen keempat pada 01

b. (Iqamah al-Adl (Menegakan keadilan).

Indikator kinerja untuk tujuan yang kedua IK (02) yaitu:

$$
\begin{aligned}
\text { IK } 02= & W^{2} x E^{5} x R^{5}+W^{2} x E^{6} x R^{6} \\
& +W^{2} x E^{7} x R^{7}
\end{aligned}
$$

Atau disederhanakan menjadi :

IK $02=W^{2}\left(E^{5} x R^{5}+E^{6} x R^{6}+E^{7} x R^{7}\right)$

Keterangan :

IK 02 : Indikator kinerja pada tujuan pertama dari Maqashid Syariah Iqamah al-Adl (Menegakan Keadilan)

$W^{2}$ : Bobot Variabel untk Iqamah al-Adl (Menegakan Keadilan)

$E^{5} \quad$ : Bobot untuk elemen kelima pada 02 (Pengembalian yang Adil)

$E^{6} \quad$ : Bobot untuk elemen keenam pada 02 (Distribusi Fungsional)

$E^{7} \quad$ : Bobot untuk elemen ketujuh pada 02 (Pendapatan Bebas Bunga)

$R^{5} \quad$ : Rasio kinerja untuk elemen kelima pada 02

$R^{6} \quad$ : Rasio kinerja untuk elemen keenam pada 02

$R^{7} \quad$ : Rasio kinerja untuk elemen ketujuh pada 02

c. Jabl al-Maslahah (Menciptakan Kemaslahatan)

Indikator kinerja untuk tujuan yang kedua IK (03) yaitu:

IK $03=W^{3} x E^{8} x R^{8}+W^{3} x E^{9} x R^{9}+$ 


$$
W^{3} x E^{10} x R^{10}
$$

Atau disederhanakan menjadi : IK $02=W^{3}\left(E^{8} x R^{8}+E^{9} x R^{9}+E^{10} x\right.$ $\left.R^{10}\right)$

Keterangan:

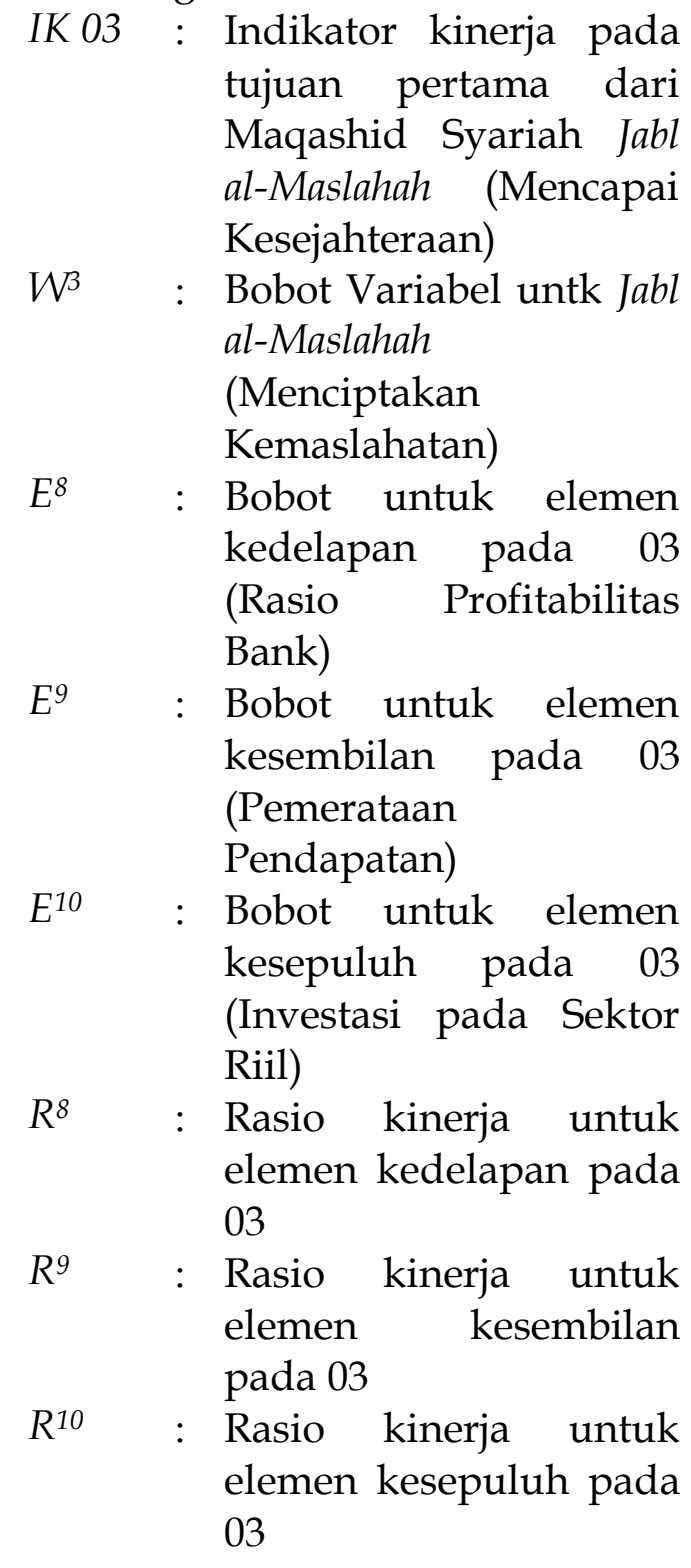

Menentukan Sharia Maqashid Index (SMI) pada setiap Bank Umum Syariah.

Sharia Maqashid Index (SMI) untuk setiap Bank Umum Syariah merupakan total semua Indikator Kinerja dari 3 tujuan maqashid syariah yaitu Tahzib al-Fard (Mendidik Individu) atau IK (01), Iqamah aladl (Menegakan Keadilan) atau IK (02), dan $J a b l$

al-Maslahah

(Menciptakan
Kemaslahatan) atau IK (03). Secara matematis, dapat digambarkan sebagai berikut:

$$
S M I=I K(01)+I K(02)+I K(03)
$$

Mengurutkan Peringkat Bank Umum Syariah berdasarkan Total Nilai Sharia Maqashid Index (SMI).

Bank Umum Syariah kemudian diurutkan berdasarkan total nilai Sharia Maqashid Index (SMI). Peringkat diberikan mulai dari total nilai tertinggi sampai terendah. Bank Umum Syariah yang memperoleh total nilai Sharia Maqashid Index (SMI) tertinggi, mendapatkan peringkat pertama dan seterusnya.

\section{HASIL DAN PEMBAHASAN}

Berdasarkan penelitian yang telah dilaksanakan, data yang telah dikumpulkan yaitu data sekunder berupa data keuangan pada Annual Report dari 14 Bank Umum Syariah yang telah diaudit. Bank Umum Syariah tersebut yaitu Bank Muamalat (BMI), Bank Syariah Mandiri (BSM), BNI Syariah (BNIS), BRI Syariah (BRIS), Bank Mega Syariah (BMS), BTPN Syariah (BTPS), Bank Panin Dubai Syariah (BPDS), Bank Victoria Syariah (BVS), Maybank Syariah (MAYBS), Bank Jabar Banten Syariah (BJBS), Bank Aceh Syariah (BAS), Bank NTB Syariah (BNTBS).

\subsection{Sharia Maqashid Index (SMI)}

Hal pertama kali dilakukan dalam perhitungan Sharia Maqashid Index (SMI) adalah mengambil data yang pada Annual Report pada masing-masing Bank Umum Syariah yaitu data hibah pendidikan, biaya penelitian, biaya publikasi, total biaya/beban operasional, total investasi, total pembiayaan, pembiyaan Mudharabah dan Musyarakah, pendapatan bebas bunga, total pendapatan, laba usaha, laba bersih, zakat, dan investasi pada sektor riil.

Data yang didapatkan kemudian dianalisis dengan menggunakan Sharia 
Maqashid Index (SMI) dan Simple Additive Weighting Method (SAW) dengan cara pembobotan, agregat dan proses menentukan peringkat, berdasarkan 3 tujuan dari Maqashid Syariah dari yaitu, Tahfidz alFard (Mendidik Individu), Iqamah al-Adl (Menegakan Keadilan) dan Jabl al-Maslahah (Menciptakan kemaslahatan).

a. Tahfidz al-Fard (Mendidik Individu)

Tujuan pertama dari Maqashid Syariah yaitu penyucian jiwa yang dikembangkan menjadi konsep tujuan meningkatkan pendidikan ${ }^{29}$. Perbuatan baik dan buruk berasal dari jiwa manusia. Sehingga dengan memiliki jiwa yang baiklah, semua perbuatan buruk akan ditinggalkan. Proses penyucian jiwa akan lebih efektif jika dipraktikkan didalam proses pendidikan mulai sejak usia dini ${ }^{30}$.

Hal-hal yang harus dilakukan Bank Umum Syariah dalam menjalankan tujuan Maqashid Syariah yang pertama yaitu Tahfidz al-Fard (Mendidik Individu) seperti, meningkatkan pendidikan masyarakat dengan memberikan bantuan beasiswa pada sekolah-sekolah, melakukan kegiatan penelitian dalam pengembangan Bank Umum Syariah, memberikan pelatihan dan pendidikan kepada para pegawai untuk meningkatkan SDM dan Skill dalam peningkatan mutu pelayanan Bank Umum Syariah, dan melakukan kegiatan sosialisasi, dan publisitas/promosi terhadap produk dan layanan perbankan syariah untuk masyarakat.

Pada tujuan mendidik individu, hasil yang didapatkan dari penelitian ini setelah dilakukan pembobotan akan ditunjukan pada tabel 4 di bawah ini: 
Tabel 4. Total Indikator Kinerja dari Tujuan Pertama (IK01) yaitu Tahfidz al-Fard (Mendidik Individu)

\begin{tabular}{|c|c|c|c|c|c|}
\hline \multirow{2}{*}{$\begin{array}{c}\text { BANK } \\
\text { SMUM }\end{array}$} & \multicolumn{4}{|c|}{ IK (01) (\%) } & \multirow{2}{*}{$\begin{array}{c}\text { Total IK (01) } \\
\text { (\%) }\end{array}$} \\
\cline { 2 - 5 } & $\begin{array}{c}\text { Hibah } \\
\text { Pendidikan }\end{array}$ & Penelitian & Pelatihan & Publikasi & 0,4426 \\
\hline BMI & 0,0133 & 0,0094 & 0,0720 & 0,3479 & 0,2073 \\
\hline BSM & 0,0175 & 0,0000 & 0,0893 & 0,1006 & 0,5537 \\
\hline BNIS & 0,0077 & 0,0000 & 0,2251 & 0,3209 & 0,1808 \\
\hline BCAS & 0,0070 & 0,0000 & 0,0578 & 0,1160 & 0,1840 \\
\hline BPDS & 0,0000 & 0,0000 & 0,1515 & 0,0325 & 0,3087 \\
\hline BMS & 0,0032 & 0,0000 & 0,1693 & 0,1362 & 0,1905 \\
\hline BSB & 0,0000 & 0,0000 & 0,1041 & 0,0982 & 0,2023 \\
\hline BTPNS & 0,0000 & 0,0000 & 0,1966 & 0,0616 & 0,2582 \\
\hline MAYBS & 0,0000 & 0,0000 & 0,0756 & 0,0386 & 0,1142 \\
\hline BVS & 0,0000 & 0,0000 & 0,0860 & 0,0764 & 0,1623 \\
\hline BJBS & 0,0000 & 0,0002 & 0,0029 & 0,2244 & 0,2275 \\
\hline BAC & 0,0036 & 0,0000 & 0,1380 & 0,0420 & 0,1835 \\
\hline BNTBS & 0,0031 & 0,0000 & 0,0763 & 0,1227 & 0,2021 \\
\hline
\end{tabular}

Sumber: Data diolah, 2020

\section{a. Hibah Pendidikan.}

Elemen pertama dari tujuan Maqashid Syariah yang pertama adalah hibah pendidikan, dengan indikator kinerja hibah pendidikan dibagi dengan total biaya. Hibah pendidikan merupakan biaya yang dikeluarkan Bank Umum Syariah sebagai bentuk kepedulian dan tanggung jawab sosial mereka terhadap dunia pendidikan. Hibah ini dapat berupa pemberian beasiswa pada sekolah-sekolah serta bantuan kepada lembaga pendidikan.

Berdasarkan tabel indikator kinerja IK(01) setelah dilakukan pembobotan pada rasio-rasio, dapat kita lihat bahwa, dari 14 Bank Umum Syariah yang menjadi objek penelitian, hanya 8

Bank Umum Syariah yang menjelaskan secara rinci mengenai biaya untuk hibah pendidikan yang disalurkan. Adapun diantaranya yaitu Bank Muamalat Indonesia, Bank Syariah Mandiri, BNI Syariah, BRI Syariah, Bank Mega Syariah, Bank Panin Dubai Syariah, dan Bank Aceh
Syariah, dan Bank NTB Syariah.

Pada tahun 2018, Bank Umum Syariah yang memiliki penyaluran dana terbesar dalam hibah pendidikan adalah Bank Syariah Mandiri yaitu sebesar Rp. 12.894.000.000 dengan persentase 0,0175\% dari total biaya yang dikeluarkan. Kemudian diikuti oleh BMI dengan persentase sebesar 0,0133\% dan BNI Syariah sebesar 0,0077\%.

Bank Syariah Mandiri menyalurkan dana hibah pendidikan berupa beasiswa Tahfidz, beasiswa Fellowship, bantuan pendidikan mahasiswa dan pelajar, bantuan sarana dan prasaranan lembaga pendidikan, dan program-program pendidikan lainnya.

Pendidikan merupakan hal yang sangat penting. Pemberian dana hibah pendidikan kepada masyarakat dalam hal ini mahasiswa, pelajar, sekolah, dan lembaga pendidikan lainnya, dapat diharapkan bisa mencetak generasi-generasi handal yang bisa memajukan pertumbuhan ekonomi syariah. Kehadiran Bank Umum Syariah bisa bertahan dan mendapatkan kepercayaan dari masyarakat dari waktu ke waktu. Hibah pendidikan yang diberikan juga 
memperlihatkan bahwa beberapa Bank Umum Syariah telah menjalankan salah satu prinsip dari Maqashid Syariah yaitu Tahfidz al Fard (Mendidik Individu)

b. Penelitian

Elemen kedua dari tujuan Maqashid Syariah yang pertama yaitu Penelitian, dengan indikator kinerja yaitu biaya penelitian dibagi total biaya. Penelitian dan pengembangan yang dilakukan oleh Bank Umum Syariah diharapkan dapat membantu memajukan ekonomi syariah di indonesia sehingga dapat memperkuat industri bank umum syariah yang berujung pada kepuasan dan kepercayaan masyarakat, pemegang saham, dan pemerintah. Atas dasar hal tersebut, maka Bank Umum Syariah mengalokasikan dana untuk kegiatan penelitian dan pengembangan.

Berdasrkan hasil tabel indikator kinerja IK(01) setelah dilakukan pembobotan pada rasio-rasio, terlihat bahwa hanya Bank Muamalat Indonesia dan Bank Jabar Banten Syariah yang merincikan alokasikan dananya dalam penelitian dengan total dana Rp. 2.080.442.000, dengan persentase sebesar 0,0094\% dari keseluruhan total biaya yang dikeluarkan perusahaan. Kemudian, disusul oleh Bank Jabar Banten Syariah dengan persentase $0,0002 \%$ dari total biaya yang dikeluarkan. Penelitian dan pengembangan pada Bank Muamalat Indonesia diharapkan dapat membuat inovasi-inovasi produk terbaru yang berdasarkan prinsip syariah sesuai dengan kebutuhan masyarakat, dan dapat menemukan solusi atas permasalahan yang dialami oleh Bank Umum Syariah saat ini.

\section{c. Pelatihan}

Elemen ketiga dari tujuan Maqashid Syariah yang pertama yaitu Pelatihan, dengan indikator kinerja yaitu biaya pelatihan dibagi dengan total biaya. Pelatihan dan pendidikan sangat penting dilakukan Bank Umum Syariah terhadap semua pegawainnya. Pelatihan dilakukan untuk meningkatkan sumber daya manusia, skill, dan motivasi para karyawan agar selalu memberikan kinerja terbaik sehingga Bank Umum Syariah bisa beroperasi dengan maksimal.

Berdasarkan hasil tabel indikator kinerja IK (01) setelah dilakukan pembobotan pada rasio-rasio, dapat dilihat bahwa, semua Bank Umum Syariah yang menjadi objek penelitian mengalokasikan dananya untuk memberikan pendidikan dan pelatihan kepada karyawannya. BNI Syariah merupakan Bank Umum Syariah dengan presentasi alokasi dana pelatihan terbesar yaitu $0,2251 \%$ dengan nilai $R p$. 44.117.000.000, kemudian diikuti oleh BTPN Syariah dengan persentase sebesar 0,1966\% dan Bank Panin Dubai Syariah dengan persentase $0,1693 \%$. Pelatihan yang dilakukan oleh BNI Syariah yaitu pelatihan manajemen resiko, pelatihan anti pencucian uang (APU PPTT), pelatihan internal control, pelatihan kepemimpinan dan pengembangan SDM, skill, serta masih banyak lagi. Pelatihan dan pendidikan sangat penting dilaksankan mengingat pegawai/karyawan merupakan "asset" yang berharga bagi bank umum syariah d. Publisitas

Elemen keempat dari tujuan Maqashid Syariah yang pertama yaitu Publisitas atau promosi, dengan indikator kinerja yaitu biaya publisitas/promosi dibagi dengan total biaya. Publisitas/Promosi sangat penting dilakukan oleh Bank Umum Syariah untuk bisa memperkenalkan citra mereka kepada masyarakat secara luas. Publikasi atau promosi yang dilakukan dapat menarik minat konsumen/nasabah yang akan 
berpengaruh pada peningkatan eksistensi Bank Umum Syariah yang signifikan. Tanpa adanya publikasi, perkembangan Bank Umum Syariah akan berjalan dengan lambat. Selain itu publikasi juga dapat menarik minat para investor maupun calon investor agar bisa berinvestasi dengan prinsip syariah, sehingga dana yang mereka investasikan bisa menjadi berkah.

Berdasarkan hasil tabel indikator kinerja IK(01) setelah dilakukan pembobotan pada rasio-rasio, dapat dilihat bahwa Bank Muamalat Indonesia memeliki persentase tertinggi yaitu 0,3479\% dari total biaya yang dikeluarkan, dengan alokasi sebesar Rp. 86.816.829.000, kemudian disusul oleh BNI Syariah sebesar 0,3209\% dari total biaya yang dikeluarkan, Bank Jabar Banten Syariah sebesar 0,2244\% dari total biaya yang dikeluarkan.

Tingginya persentasi alokasi biaya publikasi oleh Bank Muamalat Indonesia menunjukan bahwa mereka sangat serius untuk melakukan publikasi/promosi yang menarik terhadap masyarakat luas, mengingat sangat banyak keuntungan yang didapatkan oleh publikasi/promosi dalam meningkatkan minat nasabah.

Bank Muamalat Indonesia terus melakukan optimalisasi dan pengembangan dari produk, program, dan layanan dari tahun sebelumnya. Bank Muamalat Indonesia fokus untuk melakukan promosi dan pemasaran melalui digital media sesuai dengan era modernisasi yang sedang berlangsung tanpa meninggalkan traditional promotion yang sudah lebih diketahui dan diakses oleh nasabah dan masyarakat, mengedepankan layanan yang excellent, serta ikut aktif berperan dalam memberikan edukasi tentang perbankan syariah yang mudah dimengerti oleh masyarakat untuk segala Publikasi/promosi juga dititik beratkan pada prinsip syariah yaitu tidak adanya riba sehingga apa yang dilakukan menjadi keberkahan.

b. Iqamah al-Adl (Menegakan keadilan)

Tujuan Maqashid Syariah yang kedua yaitu Iqamah al-Adl (Menegakan keadilan), artinya bahwa perbankan syariah harus meyakinkan masyarakat bahwa setiap transaksi dalam setiap kegiatan bisnis dilakukan secara adil, termasuk produk, harga, syarat dan ketentuan kontrak. Selain itu perbankan syariah juga harus memastikan bahwa setiap bisnis perbankan bebas dari unsur-unsur negatif yang dapat menciptakan hal yang tidak baik seperti riba, penipuan, dan korupsi.

Menciptakan keadilan, didasarkan pada penilaian obyektif kinerja perbankan syariah untuk memastikan kejujuran dan keadilan dalam semua transaksi dan kegiatan bisnis Kepemilikan Perusahaan, termasuk dalam produk serta aktivitas transaksi keseluruhan adalah aktivitas yang bebas dari bunga ${ }^{31}$. Pada tujuan menegakkan keadilan, hasil yang didapatkan dari penelitian ini setela dilakukan pembobotan akan ditunjukan pada tabel di bawah ini.

${ }^{31}$ Sri Hartono dan Agus Sobari. "Sharia Maqashid Index as a Measuring Performance Of Islamic Banking: a More Holistic Approach", Coorporate Ownership and Control, Vol. 14, Issue 2, 2017, Page 193-201 virtusspres.org 
Tabel 5. Total Indikator Kinerja dari Tujuan Kedua (IK 02) yaitu Iqamah al-Adl (Menegakan keadilan)

\begin{tabular}{|c|c|c|c|c|}
\hline \multirow{2}{*}{$\begin{array}{c}\text { BANK } \\
\text { UYUM }\end{array}$} & \multicolumn{3}{|c|}{ IK (02) (\%) } & \multirow{2}{*}{$\begin{array}{c}\text { Total IK (02) } \\
\text { (\%) }\end{array}$} \\
\cline { 2 - 4 } BMIAH & $\begin{array}{c}\text { Pengembalian } \\
\text { yang Adil }\end{array}$ & $\begin{array}{c}\text { Distribusi } \\
\text { Fungsional }\end{array}$ & $\begin{array}{c}\text { Pendapatan } \\
\text { Bebas Bunga }\end{array}$ & 22,4210 \\
\hline BSM & 0,2373 & 6,6036 & 15,5800 & 21,5733 \\
\hline BNIS & 1,1720 & 4,8212 & 15,5800 & 21,3271 \\
\hline BRIS & 1,8739 & 3,8732 & 15,5800 & 21,4386 \\
\hline BCAS & 1,5474 & 5,2707 & 15,5800 & 25,4239 \\
\hline BPDS & 0,0745 & 8,0024 & 15,5800 & 27,7635 \\
\hline BMS & 0,7416 & 12,1089 & 15,5800 & 19,5019 \\
\hline BSB & 0,0682 & 8,1802 & 15,5800 & 24,0638 \\
\hline BTPNS & 4,6299 & 0,0000 & 15,5800 & 20,2099 \\
\hline MAYBS & $-16,0136$ & 0,0000 & 15,5800 & $-0,4336$ \\
\hline BVS & 0,4455 & 10,5135 & 15,5800 & 26,5390 \\
\hline BJBS & 0,5597 & 12,3948 & 15,5800 & 28,5345 \\
\hline BAC & 2,5718 & 1,1869 & 15,5800 & 19,3387 \\
\hline BNTBS & 2,1157 & 1,3678 & 15,5800 & 19,0635 \\
\hline
\end{tabular}

a. Pengembalian yang adil.

Elemen pertama dari tujuan Maqashid Syariah yang kedua yaitu pengembalian yang adil dengan indikator kinerja laba usaha dibagi dengan total pendapatan.

Berdasarkan tabel indikator kinerja IK(02) setelah dilakukan pembobotan rasiorasio, dapat dilihat bahwa BTPN Syariah memiliki persentase terbesar yaitu 4,6299\% dari total pendapatan dengan total laba usaha yaitu Rp. 1.302.539.000.000. Kemudian, diikuti oleh Bank Aceh Syariah dengan persentase sebesar 2,5718\%, dan Bank NTB

Syariah dengan persentase 2,1157\%.

\section{b. Distribusi Fungsional}

Elemen kedua dari tujuan Maqashid Syariah yang kedua adalah distribusi fungsional, dengan indikator kinerja yaitu jumlah pembiayan Mudharabah dan Musyarakah dibagi dengan total pembiayaan.
Berdasarkan tabel indikator kinerja IK(02) setelah dilakukan pembobotan rasiorasio, Bank Jabar Banten Syariah, memiliki persentase tertinggi yaitu sebesar 12,3948\% dari total investasi untuk membiayai ekonomi masyarakat melalui pembiayaan mudharabah dan musyarakah. Kemudian diikuti oleh Bank Panin Dubai Syariah yang memiliki persentase yang tidak jauh beda dari Bank Jabar Banten Syariah yaitu 12,1089\%, lalu Bank Victoria Syariah sebesar $10,5135 \%$.

Terdapat dua Bank Umum Syariah yang tidak menjelaskan secara rinci mengenai pembiayan Mudharabah dan Musyarakah yang disalurkan, yaitu BTPN Syariah dan Maybank Syariah.Pembiayaan Mudharabah dan Musyarakah merupakan skema pembiayaan dengan konsep kemitraan dengan memberikan keadilan bagi kedua belah pihak dengan prinsip profit and loss sharing. 
c. Pendapatan Bebas Bunga

Elemen ketiga dari tujuan Maqhasid Syariah yang kedua yaitu pendapatan bebas bunga, dengan indikator kinerja pendapatan bebas bunga dibagi dengan total pendapatan.

Berdasarkan tabel indikator $\operatorname{IK}(02)$ setelah dilakukan pembobotan rasio-rasio, dapat dilihat bahwa, semua Bank Umum Syariah yang menjadi objek penelitian ini, sudah sepenuhnya terbebas dari pendapatan bunga. Hal ini merupakan prinsip dasar Bank Umum Syariah yaitu menjauhi bunga, karena tidak sesuai dengan prinsip dan kaidah-kaidah keislaman. Sistem bunga yang diterapkan oleh Bank Konvensional, dianggap tidak menjalankan prinsip keadilan dikarenakan bank konvensional menghilangkan resiko kerugian jika sebuah usaha yang dibiayai oleh mereka mengalami kerugian.

\section{c. Jabl al-Maslahah (Menciptakan Kemaslahatan)}

Tujuan Maqashid Syariah yang ketiga yaitu Jabl al-Maslahah atau menciptakan kemaslahatan atau kesejahteraan. Tujuan ketiga, yaitu perbankan syariah harus membuat prioritas kegiatan bisnis yang memberikan manfaat lebih besar kepada masyarakat ${ }^{32}$.Dalam melakukan tujuan Maqashid Syariah yang ketiga, Bank Umum Syariah memiliki bagian dalam menciptakan berbagai macam proyek investasi dan kegiatan sosial untuk kesejahteraan masyarakat. Sehingga keuntungan atau manfaat tidak hanya dirasakan oleh Bank Umum Syariah itu sendiri, namun juga bisa dirasakan oleh masyarakat. Kemaslahatan atau kesejahteraan sangat penting dan merupakan aspek yang menjadi perhatian utama pada perbankan syariah. Untuk mewujudkan kemaslahatan yang jujur, adil, dan merata,

Bank Umum Syariah melakukan berbagai macam kontribusi untuk mencapai kesejahteraan masyarakat misalnya mengalokasikan dana untuk zakat bagi yang membutuhkan sehingga bisa menciptakan pemerataan ekonomi dimasyarakat. Selain itu.

Bank Umum Syariah juga melakukan pembiayaan pada sektor riil untuk menggerakan perekonomian masyarkat yang berkaitan langsung dengan kebutuhan dasar masyarakat, seperti investasi pada sektor vital, pertanian, peternakan, perikanan, usaha kecil dan menengah, konstruksi, manufaktur, dan lain-lain. Hal tersebut tentunya harus didukung dengan tingkat profitabilitas yang baik untuk dapat berkontribusi dan proyek investasi dan layanan sosial untuk kemaslahatan atau kesejahteraan masyarakat.

Pada tujuan menegakkan keadilan, hasil yang didapatkan dari penelitian ini setelah dilakukan pembobotan akan ditunjukan pada tabel di bawah ini:

\footnotetext{
${ }^{32}$ Ibid. Hlm 195
} 
Tabel 6. Total Indikator Kinerja dari Tujuan Ketiga (IK 03) yaitu Jabl al Maslahah (Menciptakan Kemaslahatan)

\begin{tabular}{|c|c|c|c|c|}
\hline \multirow{2}{*}{$\begin{array}{l}\text { BANK UMUM } \\
\text { SYARIAH }\end{array}$} & \multicolumn{3}{|c|}{ IK (03) (\%) } & \multirow{2}{*}{$\begin{array}{c}\text { Total IK (03) } \\
(\%)\end{array}$} \\
\hline & $\begin{array}{c}\text { Rasio } \\
\text { Profitabilitas }\end{array}$ & $\begin{array}{l}\text { Pemerataan } \\
\text { Pendapatan }\end{array}$ & $\begin{array}{c}\text { Investasi pada } \\
\text { Sektor Riil }\end{array}$ & \\
\hline BMI & 0,0077 & 0,1235 & 6,1966 & 6,3277 \\
\hline BSM & 0,0842 & 0,4621 & 9,2298 & 9,7761 \\
\hline BNIS & 0,1359 & 0,2877 & 8,4820 & 8,9055 \\
\hline BRIS & 0,0412 & 0,5737 & 6,9963 & 7,6112 \\
\hline BCAS & 0,1148 & 0,0000 & 7,8812 & 7,9961 \\
\hline BPDS & 0,0248 & 0,0000 & 9,1319 & 9,1568 \\
\hline BMS & 0,0890 & 0,2908 & 10,6349 & 11,0147 \\
\hline BSB & 0,0019 & 0,0000 & 10,2429 & 10,2448 \\
\hline BTPNS & 1,1867 & 0,0000 & 10,9016 & 12,0883 \\
\hline MAYBS & $-0,6565$ & 0,0000 & 4,2755 & 3,6190 \\
\hline BVS & 0,0306 & 0,0000 & 8,3731 & 8,4038 \\
\hline BJBS & 0,0517 & 0,0000 & 2,8220 & 2,8737 \\
\hline BAC & 0,2278 & 0,0000 & 6,5326 & 6,7604 \\
\hline BNTBS & 0,1837 & 0,0000 & 9,1328 & 9,3165 \\
\hline
\end{tabular}

Sumber: Data diolah, 2020.

a. Rasio Profitabilitas Bank

Elemen pertama dari tujuan Maqashid Syariah yang ketiga yaitu Rasio Profitabilitas Bank, dengan indikator kinerja yaitu laba bersih dibagi dengan total aset. Pada Annual Report Bank Umum Syariah, informasi mengenai rasio profitabilitas bank dapat dilihat pada rasio keuangan ROA (Return On Assets).

Berdasarkan tabel indikator kinerja IK(03) setelah dilakukan pembobotan rasiorasio, BTPN Syariah memiliki persentase paling besar yaitu $1,1867 \%$, dengan rasio profitabilitas ROA (Returnt On Assets) yaitu 12,4\% dari total aset Rp. 12.039.275.000.000. Setelah BTPN Syariah, selanjutnya diikuti oleh Bank Aceh Syariah sebesar 0,2278 \% dan Bank NTB Syariah sebesar 0,1837\%. Semakin tinggi nilai ROA, berarti perusahaan telah menunjukan pengolaan aset yang baik, dan memanfaatkan aktifitasnya untuk mendapatkan laba yang maksimal.

Tingginya rasio profitabilitas (ROA) BTPN Syariah salah satunya dikarenakan meningkatnya pembiayaan Murabahah yang disalurkan kepada nasabah prasejahtera produktif. Dari tabel indikator kinerja IK (03) di atas, bank yang mengalami kerugian pada tahun 2018 adalah Maybank syariah dengan persentase kerugian setelah dilakukan pembobotan yaitu $-0,935 \%$.

b. Pemerataan pendapatan.

Elemen kedua dari tujuan Maqashid Syariah yang ketiga yaitu pemerataan pendapatan, dengan indikator kinerja yaitu zakat dibagi dengan laba bersih. Zakat merupakan harta yang wajib dikeluarkan oleh para muzzaki (pembayar zakat) untuk diserahkan kepada mustahiq (penerima 
zakat). Dana zakat yang berasal dari Bank Umum Syariah diharapkan dapat meningkatkan kesejahteraan masyarakat, terutama masyarakat yang benar-benar membutuhkan agar kesenjangan pendapatan bisa berkurang.

Berdasarkan hasil pada tabel indikator IK(03) setelah dilakukan pembobotan pada rasio-rasio, dapat dilihat bahwa hanya 5 Bank Umum Syariah yang menjelaskan secara rinci dana zakat yang dikeluarkan yang berasal dari internal perusahaan, sedangkan Bank Umum Syariah lainnya hanya berfungsi sebagai penghimpun dana zakat yang dibayarkan oleh nasabah atau masyarakat. BRI Syariah memiliki persentase rasio yang terbesar yaitu $0,5737 \%$, kemuadian diikuti oleh Bank Syariah Mandiri dengan persentase rasio sebesar 0,4621\% dan Bank Mega Syariah sebesar $0,2908 \%$.

BRI Syariah, dalam hal penyaluran zakat, bekerja sama dengan BAZNAZ (Badan Amil Zakat Nazional) dan YBM-BRI (Yayasan Baitul Maal BRI). Pada tahun 2018, BRI Syariah mendapatkan penghargaan dari BAZNAZ, sebagai "Unit Pengumpul Zakat Terbaik Tahun 2018".

c. Investasi pada Sektor Riil
Elemen terakhir dari tujuan Maqashid Syariah yang ketiga yaitu Investasi pada Sektor Riil, dengan indikator kinerja yaitu investasi pada sektor riil dibagi dengan total investasi. Bank Umum Syariah sebagai penghimpun dana masyarakat diharapkan juga bisa memberikan kontribusi dalam menggerakkan perekonomian masyarakat.

Berdasarkan tabel indikator kinerja IK(03) setelah dilakukan pembobotan pada rasio-rasio, BTPN Syariah meraih persentase rasio tertinggi yaitu 10,9016\%, Bank Mega Syariah 10,6349\%, Bank Syariah Bukopin $10,2429 \%$. Adanya investasi pada sektor riil diharapkan bahwa Bank Umum Syariah dapat terjun langsung untuk menigkatkan perekonomian masyarakat diberbagai sektor.

d. Peringkat Kinerja Bank Umum Syariah Berdasarkan Sharia Maqashid Index (SMI).

Untuk menentukan peringkat kinerja Bank Umum Syariah berdasarkan Sharia Maqashid Index (SMI), maka hal yang dilakukan yaitu menjumlahkan total indikator kinerja dari 3 tujuan Maqashid Syariah yaitu IK(01), IK(02), dan IK(03) Pada masing-masing Bank Umum Syariah.

Tabel 7. Total Indikator Kinerja Sharia Maqashid Index (SMI)

\begin{tabular}{|c|c|c|c|c|}
\hline \multirow{2}{*}{$\begin{array}{c}\text { BANK } \\
\text { UMUM }\end{array}$} & \multicolumn{2}{|c|}{ Sharia Maqasid Index (SMI) } & \multirow{2}{*}{ TOTAL } \\
\cline { 2 - 3 } SYARIAH & $\begin{array}{c}\text { IK 01 } \\
(\boldsymbol{\%})\end{array}$ & $\begin{array}{c}\text { IK 02 } \\
(\boldsymbol{\%})\end{array}$ & $\begin{array}{c}\text { IK 03 } \\
\mathbf{( 3 \% )}\end{array}$ & $\begin{array}{c}\text { IINDIKATOR } \\
\text { KINERJA (\%) }\end{array}$ \\
\hline BMI & 0,4426 & 22,4210 & 6,3277 & 29,1913 \\
\hline BSM & 0,2073 & 21,5733 & 9,7761 & 31,5567 \\
\hline BNIS & 0,5537 & 21,3271 & 8,9055 & 30,7864 \\
\hline BRIS & 0,1808 & 21,4386 & 7,6112 & 29,2306 \\
\hline BCAS & 0,1840 & 25,4239 & 7,9961 & 33,6039 \\
\hline BPDS & 0,3087 & 27,7635 & 9,1568 & 37,2289 \\
\hline BMS & 0,1905 & 19,5019 & 11,0147 & 30,7071 \\
\hline BSB & 0,2023 & 24,0638 & 10,2448 & 34,5109 \\
\hline
\end{tabular}




\begin{tabular}{|c|c|c|c|c|} 
BTPNS & 0,2582 & 20,2099 & 12,0883 & 32,5564 \\
\hline MAYBS & 0,1142 & $-0,4336$ & 3,6190 & 3,2996 \\
\hline BVS & 0,1623 & 26,5390 & 8,4038 & 35,1051 \\
\hline BJBS & 0,2275 & 28,5345 & 2,8737 & 31,6357 \\
\hline BAC & 0,1835 & 19,3387 & 6,7604 & 26,2826 \\
\hline BNTBS & 0,2021 & 19,0635 & 9,3165 & 28,5821 \\
\hline
\end{tabular}

Sumber: Data diolah, 2020

Kemudian setelah melakukan Syariah dengan menggunakan metode penjumlahan terhadap semua indikator, Sharia Maqashid Index (SMI). Hasil Peringkat hasil yang didapatkan dirangking Bank Umum Syariah berdasarkan Sharia berdasarkan nilai tertinggi ke nilai terendah Maqashid Index (SMI) dapat dilihat pada untuk mendapatkan peringkat pertama tabel berikut. sampai peringkat terakhir Bank Umum

Tabel 8. Peringkat Kinerja Bank Umum Syariah di Indonesia tahun 2018 berdasarkan Sharia Maqashid Index (SMI)

\begin{tabular}{|c|l|c|c|}
\hline $\begin{array}{c}\text { Singkatan pada } \\
\text { Tabel Indikator } \\
\text { Kinerja }\end{array}$ & \multicolumn{1}{|c|}{ Bank Umum Syariah } & $\begin{array}{c}\text { Total } \\
\text { Indikator } \\
\text { Kinerja SMI } \\
(\boldsymbol{\%})\end{array}$ & Peringkat \\
\hline BPDS & Bank Panin Dubai Syariah & 37,2289 & 1 \\
\hline BVS & Bank Victoria Syariah & 35,1051 & 2 \\
\hline BSB & Bank Syariah Bukopin & 34,5109 & 3 \\
\hline BCAS & BCA Syariah & 33,6039 & 4 \\
\hline BTPNS & BTPN Syariah & 32,5564 & 5 \\
\hline BJBS & Bank Jabar Banten Syariah & 31,6357 & 6 \\
\hline BSM & Bank Syariah Mandiri & 31,5567 & 7 \\
\hline BNIS & BNI Syariah & 30,7864 & 8 \\
\hline BMS & Bank Mega Syariah & 30,7071 & 9 \\
\hline BRIS & BRI Syariah & 29,2306 & 10 \\
\hline BMI & Bank Muamalat Indonesia & 29,1913 & 11 \\
\hline BNTBS & Bank NTB Syariah & 28,5821 & 12 \\
\hline BAC & Bank Aceh Syariah & 26,2826 & 13 \\
\hline MAYBS & Maybank Syariah & 3,2996 & 14 \\
\hline
\end{tabular}

Sumber: Data diolah, 2020.

Dari tabel peringkat Bank Umum Syariah di atas, maka dapat dilihat bahwa Bank Panin Dubai Syariah meraih peringkat pertama dengan total nilai Sharia Maqashid Index (SMI) sebesar 37,2289\%, urutan selanjutnya yaitu Bank Victoria Syariah dengan total nilai sebesar 35,1051\%, Bank Syariah Bukopin sebesar 34,5109\%, BCA Syariah sebesar 33,6039\%, BTPN Syariah sebesar 32,5564\%, Bank Jabar Banten Syariah 
sebesar 31,6537\%, Bank Syariah Mandiri sebesar 31,5567\%, BNI Syariah sebesar $30,7864 \%$, Bank Mega Syariah sebesar $30,7071 \%$, BRI Syariah sebesar 29,2306\%, Bank Muamalat Indonesia sebesar 29,1913\%, Bank NTB Syariah sebesar 28,5821\%, Bank Aceh Syariah sebesar 26,2826\%, diurutan terakhir yaitu Maybank Syariah sebesar $3,2996 \%$. Seperti yang telah dibahas sebelumnya, Maybank Syariah pada tahun 2018 mengalami rugi operasional sebesar Rp. 88.265.000.000, dan rugi bersih sebesar Rp. 64.720.000.000. Hal tersebut menjadi salah satu faktor yang membuat hasil perhitungan Sharia Maqashid Index (SMI) untuk Maybank Syariah sangat menurun dibanding Bank Umum Syariah lainnya.

Dari hasil analisis tersebut, bahwa Bank Umum Syariah di Indonesia tahun 2018, hampir semuanya sudah menjalankan prinsip Maqashid Syariah dengan baik, namun beberapa dari Bank Umum Syariah tersebut tidak mempublikasikan atau menjelaskan secara rinci beberapa alokasi dana dalam Annual Report tahun 2018 yang menjadi data keuangan yang digunakan sebagai indikator perhitungan Sharia Maqashid Index (SMI) ini. Hal tersebut mengakibatkan, kurang optimalnya penilaian Bank Umum Syariah tersebut menggunakan Sharia Maqashid Index (SMI).

\section{KESIMPULAN DAN SARAN}

Penilaian kinerja Bank Umum Syariah, selama ini hanya dilakukan menggunakan rasio-rasio keuangan saja seperti pengukuran kinerja bank konvensional. Sehingga para ahli mengembangkan suatu metode pengukuran kinerja Bank Umum Syariah yang berdasarkan prinsip syariah dan keislaman menggunakan metode Sharia Maqashid Index (SMI) dengan menghitung tiga tujuan Maqashid Syariah yaitu Tahfidz
al-Fard (mendidik individu), Iqamah al-Adl (Menegakan keadilan), dan Jabl al-Maslahah (Menciptakan Kemaslahatan).

Berdasarkan hasil perhitungan indikator kinerja dari 3 tujuan Maqashid Syariah tersebut, dapat disimpulkan bahwa peringkat kinerja Bank Umum Syariah, dimana bank umum syariah yang meraih total nilai tertinggi yaitu Bank Panin Dubai Syariah sebesar 37,2289\% menempati urutan pertama dan Bank Umum Syariah yang memperoleh total nilai terendah yaitu Maybank Syariah sebesar 3,2996\%. Adapaun Peringkat Bank Umum Syariah mulai dari tertinggi sampai peringkat terendah yaitu Bank Panin Dubai Syariah, Bank Victoria syariah, Bank Bukopin Syariah, BCA Syariah, BTPN Syariah, Bank Syariah Mandiri, Bank Jabar Banten Syariah, BNI Syariah, Bank Mega Syariah, BRI Syariah, Bank Muamalat Indonesia, Bank Aceh Syariah, Bank NTB Syariah dan terakhir Maybank Syariah.

Setiap Bank Umum Syariah memiliki kelebihan dan kekurangan didalam melaksanakan Tujuan Maqashid Syariah, namun secara garis besar sudah bisa menjalan semua tujuannya yaitu Tahfidz al Fard (mendidik individu), Iqamah al adl (Menegakan keadilan), dan Jabl al Maslahah (Menciptakan Kemaslahatan) dengan baik walaupun beberapa Bank Umum Syariah belum mempublikasikan alokasi dana yang menjadi indikator dalam perhitungan Sharia Maqashid Index (SMI).

Dari temuan ini, diharapkan bahwa semua Bank Umum Syariah di Indonesia, bisa melakukan evaluasi dan pengembangan lebih lanjut mengenai penilaian kinerja yang cocok dan sesuai dengan prinsip syariah yang mengutamakan kemaslahatan umat.

Bank Umum Syariah diharapkan lebih memperhatikan lagi setiap alokasi 
dana yang dikeluarkan agar lebih bisa memberikan manfaat untuk masyarakat luas agar mencapai keberkahan dunia dan akhirat. Pada Akhirnya, kehadiran Bank Umum Syariah di Indonesia menjadi penggerak perekonomian indonesia.

\section{DAFTAR PUSTAKA}

Afrinaldi. 2013. Analisis Kinerja Perbankan Syariah indonesia ditinjau dari Maqashid Syariah: Pendekatan Sharia Maqashid Index (SMI) dan Profitabilitas Bank Syariah, Islamic Economic \&Finance (IEF) Universitas Trisakti, Jakarta.

Al Arif, MNR. 2012. Dasar-dasar Pemasaran Bank Syariah. Bandung: Alfabeta.

Al Ghifari, LH. 2015. Analisis Kinerja Perbankan Syariah di Indonesia dan Malaysia dengan Pendekatan Maqashid Sharia Index. Jurnal Ekonomi dan Perbankan Syariah Vol 3 No 2.

Ali, Zainuddin. 2007. Hukum Perbankan Syariah, Jakarta: Sinar Grafika.

Antonio, M. S. 2001. Bank Syariah dari Teori ke Praktik. Jakarta : Gema Insani

Antonio, M. S., Sanrego, Y. D., Taufiq, M. 2012. An Analysis of Islamic Banking Performance: Maqashid Index Implementation in Indonesia and Jordania. IIUM Institute of Islamic Banking and Finance. Journal of Islamic Finance, 1(1).

Auda, Jasser. 2015. Membumikan Hukum Islam Melalui Maqashid Syariah. Bandung: Mizan Pustaka.

Bedoui, Houssemeddine., Walid, Mansour. 2013. Islamic Banks Performance and Maqashid alShariah, Makalah Disampaikan pada Asia-Pasific Economic Association Conference, di Osaka, Jepang, 27 s.d 28 Juli

Cakhyaneu, Aneu. 2018. Pengukuran Kinerja
Bank Umum Syariah di Indonesia Berdasarkan Sharia Maqashid Index (SMI). Awaluna: Jurnal Ekonomi dan Keuangan Syariah, Vol.2, No.2, hlm 154-165.

Hartono, S., Sobari, A. 2017. Sharia Maqashid Index as a Measuring Performance of Islamic Banking: a More Holistic Approach, Coorporate Ownership and Control, Vol. 14, Issue 2, Page 193-201 virtusspres.org

Ifham, Ahmad. 2015. Ini Lho Bank Syariah! Memahami Bank Syariah dengan Mudah. Jakarta: Gramedia Pustaka Utama.

Karim, Adiwarman. 2006. Bank Islam: Analisis Fiqih dan Keuangan. Edisi Ketiga. Jakarta: PT Raja Grafindo Persada.

Mohammed, M. O., Razak, Dzuljastri, A., \& Taib, F. M. 2008. The Performance Measures of Islamic Banking Based on the Maqashid Framework. Paper Presented at the IIUM International Accounting Conference (INTAC IV). Putra Jaya Marroitt, Malaysia, 25 Juni.

Mohammed, M.O., Taib, F.M. 2009. Testing The Performance Measured Based on Maqashid Al-Shariah (PMMS) Model on 24 Selected Islamic and Conventional Banks. Malaysia: IIUM.

Nurhayati, Sri., Wasilah, 2015, Akuntansi Syariah di Indonesia. Edisi Empat. Jakarta: Salemba Empat.

Nurdin, N. (2016). The Roles of Information Technology in Islamic Bank Knowledge Management: A study of Two Syariah Banks in Palu. Hunafa: Jurnal Studia Islamika, 13(2), 181-217. https://doi.org/https://doi.org/10.2 4239/jsi.v13i2.444.181-217

Nurdin, N. (2019). Knowledge Integration Strategy in Islamic Banks. In A. Helena \& S. Bernardete (Eds.), The Role of Knowledge Transfer in Open 
Innovation (pp. 118-138). IGI Global. https:/ / doi.org/10.4018/978-1-52255849-1.ch006

Nurdin, N., \& Mir'atun, M. a. (2018). Do Government And Private Sharia Commercial Banks Practice Similar Financial Social Responsibility Disclosure. Hunafa: Jurnal Studia Islamika, 15(2), 285-321.

Nurdin, N., \& Yusuf, K. (2020). Knowledge management lifecycle in Islamic bank: the case of syariah banks in Indonesia. International Journal of Knowledge Management Studies, 11(1), 59-80. https://doi.org/10.1504/ijkms.2020.1 05073

Otoritas Jasa Keuangan (OJK). 2018. Statistik Perbankan Syariah, Jakarta. (di akses tanggal 1 Mei 2020, www.ojk.go.id).

Ramadhani, R., Evi, M., 2016, Analisis Perbandingan Kinerja Perbankan Syariah di Indonesia dan Malaysia Ditinjau dari Maqashid Sharia Index, Paper disampaikan pada Simposium Nasional Akuntansi XIX, Lampung.

Ramdhoni, M.I., Fauzan, F.A. 2020. Islamic Bank Performance: an Assesment using Sharia Maqashid Index, Sharia Comformity and Profitability, and CAMELS. Polban, International Journal of Applied Business Research. Vol. 2 No. 1, PP. 15-30.

Sekaran, Uma. 2000, Research methods for business: a skill building approach, New York: John Wiley \& Sons

Silvia, M., Andriana, I., Marwa, T. 2019. Performance of Indonesia Islamic Bank Based on Maqashid Sharia Index: Stakeholder Theory Perspective. Doarj, International Journal of Business, Accounting, and Management, Vol. 4 Issue 1. PP 1-9.

Sugiyono. 2007. Metode Penelitian Bisnis,
Bandung: Alfabeta.

Saoqi, A.A.Y. 2017 Analizing the Performance Of Islamic Banking in Indonesia and Malaysia: Maqashid Index Approach. Jurnal Ekonomi Islam Uhamka, Vol. 8, No.1 hlm 29-50

Syofyan, Andriani. 2017. Analisis Kinerja Bank Syariah Menggunakan Metode Index Maqashid Syariah di Indonesia, Jurnal Lembaga Keuangan dan Perbankan. Al Masraf, Vol 2, No. 2, hlm 145-158.

Wahyuni, Restiana. 2018, Analisis Kinerja Bank Syariah Indonesia Ditinjau dari Maqashid Syariah: Pendekatan Shariah Maqashid Index (SMI) Tahun 2016. Skripsi. Fakultas Ekonomi dan Bisnis Islam, UIN Raden Intan, Lampung.

Wiroso, 2011, Produk Perbankan Syariah. Jakarta: LPFE Usakti. 